\title{
Educational drama in the teaching of education for sustainability
}

\author{
Marie Jeanne McNaughton* \\ University of Strathclyde, UK
}

In this paper, I describe part of my research project that examines the use of Educational Drama in Education for Sustainability in the upper stages of the primary school (10- and 11-year-olds). Central to the research is a small-scale qualitative research study. Here, I describe the educational focus of the study and outline the methodology. Central to the study was a series of drama lessons (taught by me) based on environmental themes. The lessons link with some of the key aims in Education for Sustainability - to help young people to develop awareness, knowledge and concepts, to encourage positive attitudes and personal lifestyle decisions and to help them to acquire action skills in and for the environment. The locus is within the Scottish education system. A number of key data were generated during the teaching and evaluation of the lessons. These take the form of field notes, children's evaluations of their work and learning, observation schedules, taped interviews with participants and observers and videotapes of the lessons. The analysis of the data is ongoing, but already there is substantial evidence to suggest that the drama was instrumental in helping the children to achieve the learning outcomes set for the lessons. Some of that evidence is presented here. I suggest that the active, participative learning central to drama is particularly useful for allowing children to develop skills in communication, collaboration and expressing ideas and opinions. Also, the immersion in the imagined context and narrative, integral to the 'stories' in the drama, allows the children to feel sympathy for and empathy with people who are affected by environmental issues and problems. In giving the children a context for research and in helping them to plan solutions and to suggest alternatives, the drama allows the participants opportunities to rehearse active citizenship and facilitates learning in Education for Sustainability.

\section{The location of the research}

\section{Education for sustainability}

In the last decade, there has been an increasing focus of attention on the environment and on sustainable development, not just from environmental groups but in the media, in politics and among the general public. There has been growing international concern about issues such as how the Earth's resources are being depleted, the consequences of global warming, social inequality, poverty and starvation and growth in the world's population. The 1992 Earth Summit in Rio emphasized the central role of education in helping young people to understand

\footnotetext{
*Senior Lecturer, Department of Primary Education, University of Strathclyde, Southbrae Drive, Glasgow G13 1PP, UK. Email: m.j.mcnaughton@strath.ac.uk
}

ISSN 1350-4622 (print)/ISSN 1469-5871 (online)/02/040139-17 
world problems and to equip them with the skills and attitudes needed to take action to alleviate them. Those working in the education sector were charged with providing frameworks through which these aims could be achieved.

In 1990, Hungerford and Volk proposed a model of 'Environmental Education for Citizenship', which begins by raising children's awareness of and sensitivity to the environment and leads, over time, to the development of awareness of strategies for environmental action to promote sustainability. Here, the 'environment' was defined as encompassing the social, political, economic and ecological aspects of the world in which we live. Jensen (1995) and Laing and McNaughton (2001) described models of the development of children's skills in 'action competence'. Education for Sustainability was seen as central to helping children to engage in critical reflection on a wide range of environmental issues and to be able to take action to improve the world in which they live. It should aim to equip learners with the knowledge, skills and values necessary for becoming 'global citizens'. Global citizens are defined in Education for citizenship in Scotland (LTS, 2002, p. 3) as being people who, 'have a clear sense of their own identity and belonging, feel empowered to participate effectively in their communities and recognize their roles and responsibilities'.

During the last five years there have been a number of directives from the Scottish Executive and from Learning and Teaching Scotland relating to the provision of education for sustainability in the curriculum. Learning to sustain (SEEC, 1998), Scotland the sustainable: the learning process (AGESD, 1999) and Education for citizenship in Scottish schools: a paper for discussion and development (UNICEF, 2002) all emphasize the need to adopt an active and participative approach to educational provision in this area. As well as learning facts, it is seen as vital for children to explore and develop positive attitudes and values about the world in which they live and to gain the necessary skills to enable them to be confident to take action for their communities and environment. In summary, the key advice is that learners should be helped to develop:

- Awareness, knowledge and understanding-learners should develop an awareness of and sensitivity to the local and global environment. Issues of concern should be researched and analysed. Possible solutions or resolutions should be considered.

- Attitudes and personal lifestyle decisions-learners should be enabled to take an informed stance on issues and to see issues as relevant to themselves and of personal concern. They should make a personal commitment to resolving an issue.

- Action skills for a better environment-learners, working from a sound knowledge base, should be given opportunities to develop the skills to use appropriate strategies. They should be increasingly confident in their purposes and actions.

Scottish curriculum documents, including the Environmental studies 5-14 curriculum guidelines (SOED, 1993, 2000) suggest that Education for Sustainability must be a natural and integral part of the whole curriculum, not just a separate subject area. As part of the Education for Sustainability curriculum, teachers are encouraged 
to ensure that they plan teaching and learning experiences that will help children to develop the following:

- sensitivity to and appreciation of the Social and Natural environment;

- some factual understanding of environmental and social problems and issues;

- some basic ecology (not just science);

- knowledge/understanding of the social environment;

- skills to find out about and explore environmental issues;

- civic skills to influence decision making in society;

- ability to act responsibly;

- research skills and skills in communication of information about their environment.

\section{Educational drama}

In my research, I wanted to examine the possibility that many of these outcomes might be able to be addressed through the teaching and learning strategies employed in educational drama. In 1976 (in Wagner, 1976) Dorothy Heathecote used the term 'drama as a learning medium'. The 'Drama' referred to in my research is not based on pre-written scripts or performance. Rather, it is based on the theories and techniques of Heathecote and of international practitioner-researchers such as Gavin Bolton (1984, 1992) and Jonothan Neelands (1992). 'Drama in Education' (Bolton, 1984) or 'Process Drama' (O’Neill, 1995) is non-performance based, improvised and often employs the strategy of teacher-in-role. It is concerned with exploring ideas and feelings and looking at different perspectives. Working in role, both teacher and pupils are actively recreating and adapting their perceptions of the world and the people in it. Out of role, reflection and analysis of the drama helps to extend and deepen understanding of what might be termed as 'the human condition'. Although educational drama employs many of the techniques of theatre, unlike theatre, there is often no external audience for the work. In the process of participating in the drama, and during the reflection and evaluation, the participants 'live through' the drama rather than watching from the outside.

It was my hypothesis that educational drama might be able to help in the exploration of issues, in the development of communication and decision-making skills and in increasing the children's appreciation of and sensitivity to others. I examined a range of Scottish Office Education and Learning and Teaching Scotland documents such as Scotland the sustainable: the learning process (AGESD, 1999). I found no references to the use of drama in this documentation. In 2002, UNICEF commissioned a survey of the provision for Education for Citizenship in Scottish schools. Here, too, there was no evidence of the use of drama among the teaching methodologies described. A key purpose of my research was to discover whether specific techniques and processes in drama could, in fact, be added to the range of strategies used to help children to learn effectively in Education for Sustainability. 
Positive findings might encourage a broader, more integrated approach to this area of the curriculum.

\section{The inquiry questions}

I posed questions that I hoped to answer through my research. I wished to know which specific learning outcomes in Education for Sustainability might be addressed through the medium of drama. In addition, I wanted to explore how and why drama might be a useful tool in teaching and learning in this area.

\section{Methodology}

Central to the inquiry was a small-scale qualitative research study in two phases. In Phase 1, I planned and to teach the two sets of drama lessons based on sustainability/citizenship themes, one local and one global theme. Each set of lessons was to be implemented with two classes of children, Classes A and B, from two different schools. Strategies were planned for the collection of data and its subsequent analysis. In Phase 2, the lessons were to be replicated by a teacher from a different, third school with her class, Class C. By asking another teacher to independently teach and evaluate the lessons, I hoped to provide triangulation and reduce the possibilities of bias in later analysis of the children's learning. However, it is the data collected from Phase 1 that will be the main focus of this paper.

\section{The approach}

The main method used in the research was case study. In this work there was a multi-case approach as the processes (i.e. the Drama and Education for Sustainability process) and the episodes (i.e. the set of lessons) were repeated on a number of occasions using different subjects. This approach has a 'rolling' quality, with the ongoing observation and analysis process enabling the researcher to obtain feedback that could be fed into the next piece of work. Therefore, although the same lessons were repeated with each of the sample classes the objective of the research was not solely to seek replication of the outcomes. Rather, it was hoped that, by referring to and learning from earlier lessons, an accumulation of knowledge about the effects of the drama would be gained. This feature, along with participant observation, the focus on descriptive data and the holistic perspective, places this study within the scope of Action Research (Stenhouse, 1975).

\section{The sample}

I recognized that both the internal and external validity of the research will be dependent upon the decisions that are made about the scope of the lessons and the selection of the sample (Hitchcock \& Hughes, 1995). When selecting the two sample classes for my teaching I considered a number of factors, for example, the willingness of the teachers to participate by completing observation schedules and 
engaging in the follow-up class tasks. I also had to consider the age and stage of the children (upper primary). It was recognized that there were a number of variables such as the children's previous experience of drama and their pre-knowledge of environmental issues. By careful planning of the materials, by giving clear instructions to observers and by teaching the lessons myself, I hoped to minimise the external variables.

\section{The lessons}

The first set of lessons looked at a local issue-illegal dumping of rubbish and waste or 'fly-tipping' - and the effects that this had on a small community. The residents (children in role) living across from the dumping site experienced increasing levels of discomfort. They appealed for help to the local council but with limited success. Eventually, they made plans and took action to deal with the problem themselves. The lessons looked at, and acted out, the problem from different perspectives. It was asked why people dispose of waste inappropriately and the children researched ways of dealing with waste in a more environmentally friendly way. The key teacher roles were as one of the worried residents and as a local councillor who listened to the residents' complaints but told them that she could not help them until they found ways of helping themselves.

The second set of lessons looked at a global issue, the destruction of the rainforests and the effect this has, not only on the environment, but also on communities who live in and depend on the forests. The drama viewed the issue from the perspective of a group of villagers (children in role) whose homes were threatened by deforestation. Dramatic encounters occurred between the villagers and a messenger from another tribe, a forest worker and a representative from the forest clearing company (all teacher in role). Various meetings took place and finally the 'villagers' had to decide whether or not to leave the forest. The lessons explored the feelings and responses of people whose way of life is being threatened and considered the human cost of global expansion and development. It was asked if such development is sustainable.

After each drama lesson the children completed classroom-based activities. These activities included group poster making, group research into alternatives to dumping and deforestation, writing individual or group poems and writing speech bubbles giving different perspectives on the situations explored within the drama. Initial assessment of learning was undertaken by examining the range of pupils' responses both within and outwith the drama in conjunction with lists of proposed learning outcomes. Table 1 shows the range of Aims and Learning Outcomes proposed for 'The Dump' lessons. These are linked to key Knowledge and Concepts, Skills and Attitudes in Education for Sustainability. The codes used for the initial analysis of the responses of the children and the observers are also shown. The same process was also used in the analysis of the responses to the 'Rainforest' drama. 


\section{M. F. McNaughton}

Table 1. Proposed Education for Sustainability learning, linked to Aims and Learning Outcomes and codes for the analysis of the children's responses

\begin{tabular}{|c|c|c|}
\hline \multicolumn{3}{|c|}{ 'The Dump' } \\
\hline Aims and Learning Outcomes & $\begin{array}{l}\text { Education for Sustainability Concepts } \\
\text { and Knowledge }\end{array}$ & Codes \\
\hline $\begin{array}{l}\text { Aim } 1 \\
\text { To increase the children's awareness of } \\
\text { the social and environmental impact of } \\
\text { inappropriate waste disposal }\end{array}$ & $\begin{array}{l}\text { Inappropriate disposal of domestic } \\
\text { waste can have a social impact. } \\
\text { Inappropriate domestic waste } \\
\text { disposal can have an environmental } \\
\text { impact. }\end{array}$ & $\begin{array}{ll}\text { - } & \mathrm{CK} 1 \\
\text { - } & \mathrm{CK} 2\end{array}$ \\
\hline $\begin{array}{l}\text { Learning Outcome } 1 \\
\text { Children will identify a number of } \\
\text { factors which cause people to dispose } \\
\text { of waste inappropriately }\end{array}$ & $\begin{array}{l}\text { - People dump waste inappropriately } \\
\text { because of a number of reasons. } \\
\text { - Domestic waste consists of a variety } \\
\text { of materials and substances. } \\
\text { - People can respond to }\end{array}$ & $\begin{array}{ll}\text { - } & \mathrm{CK} 3 \\
\text { - } & \mathrm{CK} 4\end{array}$ \\
\hline $\begin{array}{l}\text { Learning Outcome } 2 \\
\text { Children will research and classify } \\
\text { waste in terms of its potential to be } \\
\text { recycled }\end{array}$ & $\begin{array}{l}\text { inappropriate domestic waste } \\
\text { disposal in a number of ways. } \\
\text { - People can take action on waste. }\end{array}$ & $\begin{array}{l}\text { - } \mathrm{CK} 5 \\
\text { - } \mathrm{CK} 6\end{array}$ \\
\hline
\end{tabular}

Education for Sustainability Skills

Aim 2

To develop the children's skills necessary for environmental education, particularly planning, collaborating, communicating ideas and reflecting critically

Learning Outcome 3

Children will create and present a plan which analyses how they (as residents) could take action to improve their own environment
- Cooperating (with teacher, with

- $\mathrm{S} 1$ each other)

- Collaborating (working together)

- Communicating

- Planning

- Decision making

- Inferring, speculating

- Stating own opinions

- Finding information

- Presenting information
- $\mathrm{S} 2$

- $\mathrm{S} 3$

- $\mathrm{S} 4$

- $\mathrm{S} 5$

- $\mathrm{S} 6$

- $\mathrm{S} 7$

- $\mathrm{S} 8$

- $\mathrm{S} 9$

Education for Sustainability Attitudes/values

Aim 3

To offer the children (as residents) opportunities to plan and take action to make a positive change to their environment, within the fictional context of the drama

Learning Outcome 4

Children will express personal views and take a stance on the issues of waste and recycling
- Willingness to participate in general - A 1

- Sympathy/empathy with characters - A 2

- Recognition of the issue-showing - A 3 concern

- Making ethical/value - A 4 judgements-re: dumpers; waste disposal/recycling 
The data

The undertaking of the teaching and data gathering for Phase 1 was carried out over a period of 12 weeks - approximately one school term. I worked for one half-day each week in each of the two classes, Class A and Class B. During this period, I also undertook interviews with the pupils and teachers and collected other relevant data. As I taught the lessons to the classes, the class teachers observed and completed the observation schedules. After each lesson, I talked to the teacher briefly, answering questions or clarifying points. Ongoing field notes were written after each session in school. In the final interviews, both the children and the teachers stated that they had enjoyed the drama work and that they felt that they had learned a lot.

By the end of Phase 1 of the project I had gathered a considerable and diverse range of sources of data. These included written and drawn responses, written evaluations, recordings of interviews with groups of children and teachers, teachers' observation notes, my field notes in my research diary and videotapes of my lessons. Having accumulated, sorted and transcribed this wide range of data, the next step was to make some sense of them.

\section{Strategies for analysis}

Initially, I was looking for evidence of learning and for comments which might give insights into any aspect of the teaching and learning process. Each of the stated Learning Outcomes in Knowledge, Skills and Attitudes were coded and these codes were applied to the transcriptions, as well as to the children's written responses. Using this 'top-down' strategy, a range evidence of learning was gathered. Although this was a qualitative study, some of the data could be enumerated. For example, in the children's responses in the evaluation sheets, preferences and key ideas could be counted and categorized. However, data such as the interview transcriptions and the children's written contributions were also analysed using a more open coding (Strauss \& Corbin, 1998), where all of the words or phrases which seemed meaningful were assigned codes relating to, for example, feelings, opinions, facts, memories and collaborations. Thus, patterns or trends might become evident.

\section{'The Dump' lessons: a description of the key drama techniques}

As 'The Dump' lessons are the focus for the discussion and analysis in this paper, I will give a brief illustration here of some of the drama techniques and procedures involved, specifically, Role Building, Narration, Dramatic Tension and Teacher-inRole. I will focus on the first few 'episodes' from Lessons 1 and 2. Hopefully, these descriptions, along with the analysis in the next section, will give those readers not familiar with this type of work a 'flavour' of the nature of the drama. A complete set of the procedures for these lessons may be found in 'What a dump! Using drama in environmental education' (McNaughton, 2000). 
There are a number of differences between 'living through' drama and the simulation exercises which are often employed in environmental education work.

One key difference is that the children engage in role building 'from the inside', choosing and developing their characters in the drama story rather than being presented with them on, for example, 'character cards'. At the beginning of 'The Dump' lessons, the teacher sets the scene of the story, that the class will be 'making' a drama about a group of people who have just moved into a new estate. The children go into 'families' of four or five, negotiate the roles they will take within the family - ages, relationships, jobs, general background, etc.- and talk about how they feel about moving into a new area-their aspirations and plans. This process takes a long time and is carefully guided by the teacher who asks many questions, for example, 'So, mum, how do you feel about having a new house at last?'; 'What are some of the best things about having moved to this area?', etc. The children also ask many questions of each other, thus developing a history and 'back story' for their characters. When the characters are well developed, they are asked to make plans, in role within their family groups, for how a piece of waste ground across from the estate might be developed. The plans may be quite elaborate with, for example, 'children' planning for play parks and 'old people' hoping for benches and bowling greens.

The next step in the process demonstrates another key difference between 'living through' drama and simulation. In the drama, the children 'get up on their feet' and physically act out scenes. The teacher introduces the building of a still image. The 'families' are each assigned an area in the room that is designated as 'their house'. They are told that it is early morning and that the family is gathered in the kitchen. They are asked to make a still image of what each member of the family is doing (making tea, reading the paper, etc.) When they are happy with the image, they hold the pose and the teacher begins to narrate, 'It is morning on the New Row estate. The family have gathered in the kitchen and are going about their morning routine. Mum is nagging the children to hurry up ...'. The children are asked to bring the scene to life and go about their business as their characters, miming actions and speaking to each other in role. After a few minutes, the teacher asks the children to freeze frame - to hold the position they are in - while she narrates and introduces the first dramatic tension into the story. She tells the children that someone has just opened the curtains and the family can see that, in the night, the piece of waste ground had turned into a dump. There is an old burned out car, various large household items, bags of rubbish, etc. The families are asked to go back into role and discuss everything that can be seen on the site. (At this stage, the focus changes and the children are asked to become 'dumpers'. They are then 'caught in the act' by residents and in small groups they improvise the ensuing scene. There is no script and the children reverse roles so that each child is given the opportunity to be both a resident and a 'dumper'. The drama finishes with the resident families making a still image to illustrate how they feel at the end of the day.)

In Lesson 2 yet another key technique, teacher-in-role, is employed. In 'living through' drama, the teacher sometimes works in role alongside the children. Using this technique can enable the teacher to, for example, model specific speech or 
behaviour, set the tone of the drama work, play 'devil's advocate' and, thus, introduce an element of dramatic tension. In 'The Dump' drama story, some time has passed and the dump is growing and becoming more unsightly and dangerous. The residents are told that a meeting has been arranged with a local councillor and that they should plan, in groups, everything that they will tell her about the problems they have been experiencing. When the residents are assembled 'in the local hall' the teacher explains that she will take the role of the councillor. She then enters carrying a clipboard (signifying that she is in role) and asks the residents about their problems. The children, in role, are very willing to explain these but are increasingly annoyed by the councillor's responses. ('A smell? Are you sure that this isn't coming from your own house?' 'Children being hurt? You should be looking after them better and not allowing them into dangerous places', etc.) Finally, she leaves, telling the residents that she will return when they can present her with some solutions and can think of ways to help themselves.

For the rest of the drama, the residents plan and present ideas, using in mime, movement and improvization. They achieve a measure of success and manage to raise funds, clear up the mess, instigate a 'rubbish watch' scheme and generally come up with inventive action to help themselves and their community. In the final scene, each group constructs an interview scene involving a 'journalist' from Scottish Television and they tell of their success and future plans.

\section{Two examples from the analysis process}

I have selected two examples of the analysis of the children's responses. These serve to illustrate the nature of the qualitative analysis process. Also, because they contain descriptions of aspects of the drama work, they may help to give the reader a better idea of how the lessons were implemented. Data from 'The Dump' lessons have been selected to provide continuity with the Aims and Learning Outcomes shown in Table 1 .

\section{Example 1: the children's written responses}

'A problem of litter-what can we do?' This activity was undertaken during 'The Dump' drama Lesson 2. In the drama, the residents had just had an unproductive meeting with a local council official. They had been told that the council wanted them to come up with solutions, not just problems. At the end of the meeting, in role as one of the residents, I suggested that they use a planning sheet (What can we do? Who can help us? Now? Soon? Later?) to gather their ideas. The children, working in 'family' groups, set about filling in the planning sheets with great energy and enthusiasm. Their suggestions were diverse and imaginative. After a given time, each group reported back and there was a whole-class discussion about which suggestions were the most viable. Each class had a realistic perception of which elements of their plans were most likely to succeed and which would be more 
difficult to achieve. Both classes completed the task successfully, with little difference in the quantity of or quality of the suggestions. The key suggestions that the children as residents made about how the problem of the dump could be tackled were:

- to clean up the dump themselves; to put up notices and posters urging people not to dump;

- to raise money to pay for equipment for cleaning up, deterrents such as cameras; to recycle more of their own waste;

- to contact environmental agencies, Pest Control and the local council; to gain publicity for their situation;

- ultimately, to seek to develop the area into a public recreational space.

As residents, the children were able to suggest many ways of taking control of the situation and of being proactive.

\section{Links to key knowledge, skills and attitudes}

The range of the children's responses demonstrated that in this task they have met Aims 1 and 3 and Learning Outcome 4 stated in the lesson plan. They displayed a range of knowledge about possible methods of disposing of waste appropriately and of improving the environment for the residents. This knowledge was not gained as a direct result of the drama lesson, as no direct teaching of facts occurred. However, it might be feasible to suggest that the drama facilitated the articulation of the children's prior knowledge. In addition, because the children were sharing their ideas, the accumulated knowledge was available to the whole-class group. In completing the list they demonstrated skills collaboration, expressing their ideas, reaching solutions and compiling and presenting a plan. The drama appears to have afforded the children opportunities to use these skills in a meaningful and purposeful context. Both of the teachers confirmed the children's high level of involvement and commented on their willingness to share and to present their ideas. The fact that they became so actively involved and because of the range and sustained nature of their contributions, it might be suggested that the children demonstrated attitudes of concern for the environment and empathy with the residents.

\section{Example 2: 'The Dump' lessons: interviews with the children}

At the end of the set of lessons and after they had completed the individual evaluation sheets, the children were interview by me. The purpose of the interview was to allow the children to express their ideas and views more fully by giving them the chance to elaborate on answers given in their written evaluations. The interviews were semi-structured. A number of categories of themes emerged from the children's responses. These, and their possible links with Education for Sustainability, are summarized in Table 2 . 
Table 2. Education for Sustainability learning linked to themes from the interviews with Classes $\mathrm{A}$ and $\mathrm{B}$

Evidence of Education for Sustainability learning from 'The Dump' interviews with Classes A and B

\begin{tabular}{|c|c|c|c|}
\hline Themes & $\begin{array}{l}\text { Examples of children's } \\
\text { comments }\end{array}$ & $\begin{array}{l}\text { Aims and } \\
\text { Learning } \\
\text { Outcomes }\end{array}$ & $\begin{array}{l}\text { Links to Key } \\
\text { C/K, S \& A }\end{array}$ \\
\hline $\begin{array}{l}\text { Recall of } \\
\text { environmental and } \\
\text { community links in } \\
\text { events in the drama }\end{array}$ & $\begin{array}{l}\text { The community got together to } \\
\text { have a meeting; } \\
\text { The councillor had answers but } \\
\text { she caused tension; } \\
\text { The people started discussing } \\
\text { how we could help ourselves; } \\
\text { We got stuff done ourselves; } \\
\text { Everything was cleared up in the } \\
\text { end; It was hard work. }\end{array}$ & Aims $1 \& 2$ & $\begin{array}{l}\text { CK } 1 \\
\text { CK } 5\end{array}$ \\
\hline $\begin{array}{l}\text { Recall of } \\
\text { environmental } \\
\text { concerns in the } \\
\text { drama }\end{array}$ & $\begin{array}{l}\text { We found rubbish; You could } \\
\text { really picture it; } \\
\text { The dump was smelly and } \\
\text { horrible; } \\
\text { It was dangerous; People's } \\
\text { children and animals were } \\
\text { getting hurt; Kids could get } \\
\text { trapped. }\end{array}$ & Aim 1 & $\begin{array}{l}\text { CK } 2 \\
\text { S } 7 \\
\text { A } 3\end{array}$ \\
\hline $\begin{array}{l}\text { Concern for the } \\
\text { environment }\end{array}$ & $\begin{array}{l}\text { How can people drop stuff like } \\
\text { that; } \\
\text { You should care about the } \\
\text { environment. }\end{array}$ & LO 4 & $\begin{array}{l}\text { S } 7 \\
\text { A } 4\end{array}$ \\
\hline $\begin{array}{l}\text { Empathy with and } \\
\text { sympathy for the } \\
\text { residents }\end{array}$ & $\begin{array}{l}\text { It must be so upsetting; } \\
\text { The people were really angry; I } \\
\text { felt really mad; sad; embarrassed; } \\
\text { I was ashamed to invite anyone } \\
\text { round; } \\
\text { The dump being cleared up was } \\
\text { a relief. }\end{array}$ & $\begin{array}{l}\text { Aim } 2 \\
\text { LO } 4\end{array}$ & $\begin{array}{l}\text { CK } 1 \\
\text { S6 } \\
\text { A } 2\end{array}$ \\
\hline $\begin{array}{l}\text { Awareness of ways to } \\
\text { take action for the } \\
\text { environment and } \\
\text { community } \\
\text { Involvement in } \\
\text { activities outwith the } \\
\text { drama lessons }\end{array}$ & $\begin{array}{l}\text { Don't dump; Don't drop litter; } \\
\text { Recycle things; } \\
\text { The community can get } \\
\text { together; } \\
\text { Don't give up. } \\
\text { We made recycle bins; recycle } \\
\text { signs; } \\
\text { People put things in to be } \\
\text { recycled; } \\
\text { We looked at how much rubbish } \\
\text { is produced in the house. }\end{array}$ & $\begin{array}{l}\text { Aim } 1 \\
\text { LO } 1\end{array}$ & $\begin{array}{l}\text { CK } 4 \\
\text { CK } 6 \\
\text { S } 9\end{array}$ \\
\hline
\end{tabular}


Table 2. (continued)

Evidence of Education for Sustainability learning from 'The Dump' interviews with Classes A and B

\begin{tabular}{|c|c|c|c|}
\hline Themes & $\begin{array}{l}\text { Examples of children's } \\
\text { comments }\end{array}$ & $\begin{array}{l}\text { Aims and } \\
\text { Learning } \\
\text { Outcomes }\end{array}$ & $\begin{array}{l}\text { Links to Key } \\
\text { C/K, S \& A }\end{array}$ \\
\hline $\begin{array}{l}\text { Awareness of } \\
\text { dramatic conventions }\end{array}$ & $\begin{array}{l}\text { Trying to sound real; } \\
\text { Everyone was getting into } \\
\text { character. }\end{array}$ & Aim 2 & S 3, 6 \\
\hline Acting 'As if ...' & $\begin{array}{l}\text { It felt real when you were acting; } \\
\text { You knew it was your } \\
\text { imagination. }\end{array}$ & Aim 2 & $\mathrm{~A} 1$ \\
\hline $\begin{array}{l}\text { Reflections on work } \\
\text { of self and peers }\end{array}$ & $\begin{array}{l}\text { Everyone in our class seems to } \\
\text { care about the environment; } \\
\text { People kept going and didn't } \\
\text { give up; } \\
\text { We all got on well; we found out } \\
\text { more about each other; } \\
\text { I feel more confident; better at } \\
\text { asking questions; better at } \\
\text { standing up for something. }\end{array}$ & Aim 3 & $\begin{array}{l}\text { A } 1 \\
\text { A3 }\end{array}$ \\
\hline
\end{tabular}

\section{Links to key knowledge, skills and attitudes}

There were a number of statements demonstrating that the children understood something of the social and environmental impact of inappropriate disposal of domestic waste. They were able to explain clearly the effects that the 'dumping' in the drama had on the lives of individuals and the community. They listed a number of emotional reactions that victims of dumping might experience. There is evidence that the children were aided in their understanding through the experience of the drama. For example, they described in detail a number of the physical features of the area in which the drama was set. They also described the dangers to people and to the environment. The drama seemed to help the children to imagine themselves in the situation and gain a strong visualization of the scene. Some children even described smelling the rubbish. The activities undertaken as part of the lessons, but outwith the drama, seemed to help the children gain a knowledge of what constitutes domestic waste and what can be done to help to minimize it. However, this knowledge might have been gained through classroom-based activities alone and there is no evidence that the drama was particularly influential here.

The children's statements indicate that a wide range of skills were practised, and perhaps developed, during the lessons. There were many references to working together and getting together. They often referred to themselves as 'the community' 
or 'everyone' and it is notable that many of the pronouns used were in the first person plural-we, us, our-indicating a strong sense of collaboration and inclusivity. There are indications that the children were aware of the need to communicate their ideas and to make decisions while working in role as residents - they had to discuss things and get things done. There is evidence that they employed a sophisticated level of skills in communication. For example, the teacher in role as the council official was a technique used to challenge their opinions and expectations and the children were aware that they had to explain their case well and to offer reasoned arguments and responses. They described their behaviour at the meeting as 'controlled' and said that they knew that 'you had to express things clearly' to make the council official understand.

There is evidence in the children's statements of a high level of affective engagement in the learning. There were many expressions of sympathy for the residents. The children were able to describe in some detail, a range of specific feelings that the people might have experienced. Particularly compelling is the fact that much of this description is in the first person-'I was ashamed ...', 'I felt really mad ...', 'It was disgusting so near your house ...'. This indicates that the children perhaps felt some empathy with the residents and were concerned for their situation. If this is the case, the first-hand experience of 'being' the residents and 'living through' an episode in their lives in the drama might have given them an insight not always accessible through more traditional, classroom-based study. The children were very able to comment on the quality of their own learning. Many described themselves as more confident, more able to speak out, better at asking questions and 'better at standing up for something'. The drama allowed them many opportunities to develop these skills and thus to feel more empowered. They also seemed to think that the drama helped them to get to know the other children in their class better and to provide them with opportunities to work together in different ways. Finally, they expressed a positive attitude towards the drama work and said that knowing they had a drama lesson gave them 'something to look forward to'.

\section{Summary of the key learning}

From the analysis of the data, it emerged that there were several areas of learning in Education for Sustainability where the drama seemed to be particularly useful.

\section{Sympathy/empathy}

In drama, participants often put themselves 'in others' shoes'. They try to act like another person, in another situation at another time. They say what that person might say and they try to imagine how that person might respond or feel. Out of drama, they reflect on what has happened and evaluate the 'truthfulness' of the 
meanings and messages they have constructed in their work. How did the people in the drama story feel? Why did they behave as they did? How do we feel about the problem? What do we believe?

Evidence of this sympathy and empathy were to be found throughout the lessons, in the children's comments both in the drama and in post-drama discussion, in their follow-up tasks and in their evaluations. This empathy is illustrated in the example of poetry written by the children as part of the 'Rainforest' lessons.

Our Rain Forest

Our forest is being destroyed.

Our children are getting hurt.

Yellow monsters are coming to eat all the trees.

Animals' homes are being destroyed.

Our river is dirty and unsafe to drink.

We are loosing food fast

Because they are killing all the animals.

Everything around us is being destroyed

And by the end of this we will have nothing

To survive on.

I wish the yellow monsters would die!

(Sharon D.)

\section{Skills in communicating, collaborating and expression ideas and opinions}

Drama allows children to rehearse and develop the skills they will need for active citizenship in a safe and non-threatening situation. They participate in fictional contexts, but they use real knowledge and real skills. Booth (1994) states that drama is a social process and that in order to participate effectively in classroom drama, pupils need to listen to and be concerned about the ideas of others. The dramatic process relies on individuals being willing and able to collaborate to recreate or to make an event or a situation. Many of the skills necessary for successful interaction in drama are also the skills needed to be effective members of the local and global community. For example, throughout 'The Dump' lessons the children had to work collaboratively to prepare their case to put to the local councillor, to research alternatives to illegal dumping, to prepare and carry out a plan to improve their area and to report on their difficulties and successes. After the 'Rainforest' drama, the children, using Internet resources, prepared booklets and posters describing the problems caused by deforestation and advising people on the steps they could take to help to reduce the destruction, for example avoiding buying tropical hardwood from non-sustainable sources and avoiding eating hamburgers. Much of this work was done at home in their own time.

\section{Exploring values}

A range of ideas and values about the environment were explored through the drama. Norman, (1999) states that, 'drama is uniquely suitable for use by those who 
perceive themselves as educator rather than subject experts-those who wish to provide learning opportunities across a wide range of personal, social, political and ethical issues' (p. 9). Both drama scenarios provided the children with many opportunities to explore a range of values. In 'The Dump' drama, working in role as 'dumpers' they had to plan and carry out the task of dumping a large piece of old furniture on the waste ground. Then, some roles were switched and 'residents' confronted some of the 'dumpers' who tried to justify their actions. (Some just denied that they had done anything, despite the evidence!) Out of role, the values and motives of the 'dumpers' and 'residents' were examined. One child said, 'When I dumped that big couch, I didn't really think about it. I just wanted to get rid of it and that seemed the easiest way.'

\section{$A$ context for research}

The drama gave the children a meaningful context through which they could extend their knowledge and ideas about the environment. After the lessons, often as result of questions raised during the drama, groups and individuals undertook research into aspects of waste disposal, recycling and also studied many aspects of rainforests and deforestation. The drama stimulated the children to engage with their learning, to make a personal reconstruction of knowledge and thus, perhaps, to come to a fuller and more meaningful understanding.

Why, then, might the drama have been a useful tool for learning, here?

\section{Imagination and modes of learning}

Egan (1992) describes how young children were observed while engaging in imaginative dramatic play. The children speculated about possibilities and outcomes when trying to find solutions to problems arising from the drama. He described this as the 'What if ...' function of the imagination. In the classroom drama, 'What if ...?' questions often played a central role in the creation of dramatic situations: 'What if we are thrown off our land?' ask the rainforest people. 'What if our children are hurt playing in the dump?' ask the residents.

When asking learners to examine problems and find solutions using a 'What if ...' strategy, drama requires the participants to envision possibilities and alternatives. This 'What if ...?' strategy is not unique to drama. However, imagining in drama goes beyond mental visualization and requires the learners to physicalize and vocalize the problem or event. Nicholson (1999) describes how drama allows participants to communicate using different 'languages'_-'visual, aural, kinaesthetic/ tactile and verbal'. In enabling children to act out situations or issues using different modes of expression, drama offers a unique experience in visioning the future.

Bolton (1984) describes another central process of the imagination in classroom drama as being able to engage in 'As if ...' behaviour. The children and the teacher strive together to engage in an extended piece of pretending. All the participants know that the situation is not real-that they are not residents, that they are not in the rainforest-but each member of the group engages in a willing suspension of 
disbelief in order to make the drama 'work'. Everyone behaves 'as if' the situation is real. It is this experience of inhabiting both the real world and the imagined world, and being aware of both, which allows a deep level of cognition, and thus learning, to take place.

\section{'Living through' drama and experiential learning}

The conceptual link between Education for Sustainability and Drama may be made through the areas of 'experiential learning' and 'imagination in learning'. Kolb (1984) states that experiential learning is holistic and integrated, combining experience, perception, cognition and behaviour. Learning is a process whereby concepts are derived from and modified by experience. In drama, the participants can have direct experience of 'living through' drama (O'Neill, 1995) in which they improvise in role in imagined situations. Egan (1992) states that imagination is 'the ability to hold alternative concepts in the mind and assess their adequacy or appropriateness' (p. 36). It is, he says, the development of the 'narrative capacities of the mind' which are so central to our general capacity to make meaning out of our experiences.

\section{Drama, story and metaphor}

The use of the narrative form in drama contributes to its usefulness as a way of teaching and learning about ourselves and others. All cultures engage in story and play as a way of teaching, passing on information and enabling the understanding of important events and issues. Winston and Tandy (1998) suggest that drama brings together two basic human activities, play and story telling, and that 'it is through achieving the distance afforded by fiction that we can reflect more securely upon issues which have significant effects upon our lives'. In drama, the children are not passive recipients of the story but are, instead, active participants in the events, tensions, problems and solutions.

Engaging the children in the story behind the environmental facts may put the ideas in context and give them a 'particular' on which to focus. This can then be extended out to general facts and understandings. But the environmental story may also be a metaphor for real life. A drama about people living near a dump, for example, is a story in itself, but it may also be a metaphor for situations where people feel 'dumped upon' or are made uncomfortable because of the actions of others. The power of the drama is not simply that it teaches facts about the environment but that the narrative is a metaphor for environmental issues. Universal environmental concepts such as oppression, dispossession and the misuse of natural and human resources lie at the heart of educational drama for sustainability.

\section{Notes on contributor}

Marie Jeanne McNaughton is a Senior Lecture in Primary Education at the University of Strathclyde, Glasgow. She is the Environmental Studies coordinator for the B.Ed. (Hons) course. She is involved in a number of initiatives for 
the promotion of Education for Sustainability in Scottish schools. She is also Secretary of National Drama and is editor of Reflections newsletter and Drama: the journal of National Drama. She runs drama courses for teachers and has published a number of papers, articles and resource materials for teachers on the use of Drama as a learning medium. Correspondence: Senior Lecturer, Department of Primary Education, University of Strathclyde, Southbrae Drive, Glasgow G13 1PP, UK.

\section{References}

AGESD (Advisory Group on Education for Sustainable Development) (1999) Scotland the sustainable: the learning process (Edinburgh, The Scottish Office).

Bolton, G. (1984) Drama as education: an argument for placing drama at the centre of the curriculum (London, Longman).

Bolton, G. (1992) New perspectives on classroom drama (Hemel Hempstead, Simon and Schuster Education).

Booth, D. (1994) Story drama: reading, writing and roleplay across the curriculum (Ontario, Pembroke Publishers).

Egan, K. (1992) Imagination in teaching and learning age 8-15 (London, Routledge).

Hitchcock, G. and Hughes, D. (1995) Research and the teacher-a qualitative introduction to school-based research (London, Routledge).

Hungerford, H. R. \& Volk, T. L. (1990) Changing learner behaviour through environmental education, fournal of Environmental Education, 21, 8-21.

Jensen, B. B. (1995) Concepts and models in a democratic health education (Copenhagen, Royal Danish School of Educational Studies).

Kolb, D. (1984) Experiential learning: experience as the source of learning and development (London, Prentice-Hall).

Laing, M. \& McNaughton, M. J. (2001) Environmental education should take children further, Scottish Educational Review, 32(2), 168-179.

LTS (2002) Education for citizenship in Scotland: a paper for discussion and development (Dundee, Learning and Teaching Scotland).

McNaughton, M. J. (2000) What a dump! Using drama in environmental education, Drama: the Fournal of National Drama, 7(2), 4-9.

Neelands, J. (1992) Learning through imagined experience (London, Hodder \& Stoughton).

Nicholson, H. (1999) Walking with shadows, in: C. Lawrence (Ed.) Canterbury keynotes (London, National Drama Publications).

Norman, J. (1999) Brain right drama, Drama: the fournal of National Drama, 6(2), 8-13.

O’Neill, C. (1995) Drama worlds: a framework for process drama (Portsmouth, NH, Heinemann).

Scottish Office Education Department (1993) National Guidelines: Environmental Studies 5-14 (Edinburgh, HMSO, Scotland).

Scottish Office Education Department (2000) Environmental studies, society, science and technology: 5-14 guidelines (Dundee, Learning and Teaching Scotland, Scotland).

SEEC (1998) Learning to sustain (Stirling, Scottish Environmental Education Council).

Stenhouse, L. (1975) An introduction to curriculum research and development (Oxford, Heinemann Educational Books).

Strauss, A. \& Corbin, J. (1998) Basics of qualitative research: techniques and procedures for developing grounded theory (Thousand Oaks, CA, Sage Publications).

UNICEF (2002) Education for citizenship in Scottish schools: a paper for discussion and development: a paper for discussion and development (London, UNICEF UK).

Wagner, B. J. (1976) Dorothy Heathcote, drama as a learning medium (London, Hutchinson).

Winston, J. \& Tandy, M. (1998) Beginning drama 4-11 (London, David Fulton Publishers). 
